\title{
Significance of anti-entactin antibodies in patients with systemic lupus erythematosus and related disorders
}

\author{
Ramesh Saxena, Gunnar Sturfelt, Ola Nived, Jörgen Wieslander
}

\begin{abstract}
Objectives-To further evaluate the association of anti-entactin antibodies with clinical manifestations in patients with systemic lupus erythematosus (SLE) and related disorders.

Methods-Sera were analysed for antienactin antibodies from 79 patients with SLE, 38 patients with systemic vasculitides, 25 patients with rheumatoid arthritis, 20 patients with progressive systemic sclerosis and five with Behçet's syndrome. Sera from 150 healthy blood donors and 20 patients with pneumonia were analysed as controls. To study the association of antientactin antibodies with severity and activity in SLE, 30 patients were assigned into three groups with 10 patients in each: (1) with mild manifestations; (2) severe disease without renal involvement and (3) frank lupus nephritis. Two blood samples from each patient were analysed, one from the active and the other from the inactive phase of the disease. Additionally, serial sera from 12 patients with SLE were also analysed.
\end{abstract}

Results-Thirty one patients with SLE (39\%) had IgG, IgM or both antientactin antibodies. Twenty three of these patients $(29 \%)$ had biopsy verified glomerulonephritis and $12(50 \%)$ were positive for anti-entactin antibodies. Of the remaining 56 patients without apparent renal involvement, $18(36 \%)$ were positive for anti-entactin antibodies. (chi squared $=2 \cdot 77, p>0 \cdot 05$ ). With the exception of rheumatoid arthritis where six patients $(24 \%)$ had IgM anti-entactin antibodies, the antibodies were present much less frequently in other diseases (two patients with systemic vasculitis whilst none of the patients with PSS or Behçet's syndrome). Only one patient with pneumonia and none of the 150 sera from healthy blood donors had antientactin antibodies. Among Group 1, three $(30 \%)$ were positive for IgG or IgM anti-entactin antibodies. Six $(60 \%)$ patients in group 2 , and five patients $(50 \%)$ in group 3 were positive for anti-entactin antibodies. However, the difference between the presence of anti-entactin antibodies between group 1 and 2 or between group 1 and 3 was not significant $(p=0.15$ and 0.19 respectively). There was no significant correlation between the titres of anti-entactin antibodies and total serum concentration of $\operatorname{IgG}(r=0 \cdot 141$, $p>0 \cdot 10)$ and IgM. $(r=0 \cdot 130, p>0 \cdot 10)$. Furthermore, no significant correlation was observed between SLE disease activity index (SLEDAI) scores and the titres of $\operatorname{IgG}(r=0.067, p>0.10)$ or $\operatorname{IgM}(r=-0.033, p>0.10)$ anti-entactin antibodies.

Conclusion-The study demonstrates that anti-entactin antibodies are present in a significant number of patients with SLE and tend to be more common in those with severe disease, with or without nephritis, than in patients with mild disease manifestations. There is no correlation between the titre of anti-entactin antibodies and severity or activity of SLE.

(Ann Rheum Dis 1994; 53: 659-665)

The glomerular basement membrane (GBM) is an extracellular matrix sandwiched between the glomerular capillary endothelial cells and the visceral epithelial cells (podocytes) of the Bowman's capsule. ${ }^{1}$ The backbone of GBM is formed by the so called 'Chicken wire network' of type IV collagen. ${ }^{2}$ Additionally, there are certain attachment proteins like laminin and entactin that bind the type IV collagen to the adjacent cell layers. ${ }^{3} 4$

Entactin, or nidogen, a $150 \mathrm{kD}$ dumbbell shaped, non collagenous glycoprotein, is a ubiquitous component of basement membranes. $^{5-8}$ Recently, we observed that two distinct groups of patients with glomerulonephritis (GN) possess circulating antibodies to entactin. ${ }^{9} 10$ One group comprised young patients with primary proliferative $\mathrm{GN}$ whereas the other consisted of middle aged patients with GN secondary to systemic lupus erythematosus (SLE) and SLE like collagen vascular diseases. ${ }^{9} 10$

SLE is a multi-system autoimmune disorder characterised by the presence of a number of circulating auto-antibodies. Some of these auto-antibodies are associated with certain distinct clinical features of SLE. One example is anti-cardiolipin antibodies that are associated with arterial thrombosis in SLE. ${ }^{11-13}$ Similarly, anti ds-DNA antibodies correlate with the severity and flares of SLE. ${ }^{14}$ These antibodies have also been associated with lupus nephritis. ${ }^{14}$ However, the pathogenic role of anti-DNA antibodies or DNA-anti DNA immune complex in lupus nephritis is widely disputed. ${ }^{15-19}$ On the other hand, anti-GBM 
(anti-laminin) antibodies have been observed in kidney eluates in experimental models of lupus nephritis, suggesting a possible pathogenic significance..$^{20-22}$ Thus, our finding of anti-GBM (anti-entactin) antibodies in patients with GN secondary to SLE hinted at a possible association and a pathogenic significance of these auto-antibodies in lupus nephritis. ${ }^{9}{ }^{10}$ However, only a small number of patients with biopsy verified lupus nephritis were included in that study. ${ }^{10}$ Consequently, the prevalence and significance of anti-entactin antibodies in patients with SLE and related diseases without renal involvement remained unknown.

The objective of the present study, was to analyse anti-entactin antibodies in a large number of patients with SLE and other related rheumatic diseases with or without kidney involvement to determine the association and significance of anti-entactin antibodies in these disorders.

\section{Materials and methods \\ DEFINITIONS}

The diagnosis of SLE was made, according to Fries and Holman, ${ }^{23}$ as the presence of typical multisystemic disease in combination with immunological abnormality and the absence of better alternative diagnosis explaining the symptoms. Furthermore, the diagnosis of all patients was continuously re-evaluated, thus excluding patients with evidence of other connective tissue diseases. The modified American Rheumatology Association (ARA) criteria $^{24}$ were not used in diagnosis, but only for the classification of SLE. The disease activity of SLE was objectively assessed by systemic lupus erythematosus disease activity index (SLEDAI). ${ }^{25}$

Primary systemic vasculitides were classified according to the American College of Rheumatology 1990 criteria. $^{26}$ Rheumatoid arthritis was defined according to the 1987 ARA criteria. ${ }^{27}$

\section{PATIENTS}

Patients with SLE

\section{(1) Epidemiological Study}

In January 1981 a prospective study was started in Southern Sweden with the purpose of identifying and monitoring all adult cases of SLE within a defined population. ${ }^{28}$ Methods of retrieval of incidence cases were developed and validated. ${ }^{29}$ By December 1986, 86 patients had been included and sera were available from 79 of these patients, 13 of whom were men. The median age was 50 years, (range 24-78

Table 1 Cumulative organ system involvement in the study group $(n=79)$. Numbers are percentages

\begin{tabular}{ll}
\hline Manifestations & $\%$ \\
\hline Musculoskeletal & 98 \\
Mucocutaneous & 75 \\
Serositis & 64 \\
Haematological & 48 \\
Neuropsychiatric & 44 \\
Glomerulonephritis & 29 \\
\hline
\end{tabular}

years). All patients had a multisystemic disease and all but two patients fulfilled the ARA criteria for the classification of SLE. The serum sample obtained at the patients first visit at the SLE clinic were used for the present study. Most patients $(78 \%)$ has a stable disease without active organ manifestation at the time of sampling. The cumulative organ manifestations of the patients are shown in table 1 . These manifestations are not ARA criteria for classification of SLE but are cumulative organ manifestations.

\section{(2) Selected SLE patients}

We also examined sera from 30 patients with SLE, prospectively followed at the SLE clinic for 10-42 months. All of these patients had developed one or more flare ups of disease activity during the observation period. Sera were sampled during exacerbation, at the point of maximal disease activity before treatment was started, and during quiescent disease (at the time of maximal clinical improvement and clinical stability). The first flare up was selected for the study in patients with more than one flare up during the observation period. The interval between the two occasions selected for investigation varied from four to 12 months.

The patients were assigned to three different groups according to manifestations presented at flare up during the observation period. Major and minor SLE manifestations were distinguished essentially as described by Lightfoot and Hughes. ${ }^{30}$ Group 1 consisted of 10 women with mild extrarenal disease restricted to the skin and to musculoskeletal system. Groups 2 and 3 consisted of two men and eight women in each, all with major manifestations. Group 2 patients all showed extrarenal symptoms only and in Group 3, evidence of significant renal involvement was present in all patients. Active renal involvement was shown by urinalysis and repeated measurement of renal functions: blood pressure, serum creatinine, BUN and glomerular filtration rate determined by $\mathrm{Cr}$ EDTA clearance. Renal disease was further documented by biopsy in all patients with group III. Light microscopy showed proliferative glomerulonephritis in six patients, membranous in one and unclassifiable glomerulonephritis in three patients. Three patients in group 2 and nine in group 3 were treated with cytostatic drugs. In six of group three patients, plasmapheresis was performed for short periods (1-2 weeks) as an adjunct to immunosuppression. Age of entry varied between 16 and 60 years with a median of 38 years in groups 1 and 2 and of 32 years in group 3. Duration of disease from the time of diagnosis was $0-22$ years, with a median of two years in each group.

(3) Serial analysis of anti-entactin antibodies We also analysed sequential sera from 12 patients with SLE seen at two months interval for one year. Sera were obtained during the active phase of the disease at the time of initial visit and then at two months interval for one year following the start of treatment. Two 
patients belonged to Group 1, seven to Group 2 while three had Group 3 manifestations. Titres of anti-entactin antibodies were compared with the SLEDAI scores.

\section{Patients with other diseases}

In addition to the patients with SLE, sera from other systemic connective tissue diseases were studied.

Thirty eight patients with primary systemic vasculitis, ${ }^{26} 25$ with rheumatoid factor positive rheumatoid arthritis, ${ }^{27} 20$ with progressive systemic sclerosis ${ }^{31}$ and five with Behçet's syndrome. ${ }^{32}$

All patients with systemic vasculitis had crescentic glomerulonephritis on renal biopsy. None of the patients with rheumatoid arthritis, progressive systemic sclerosis and Behçet's syndrome had renal disease.

\section{Control Group}

The control group consisted of: (1) Twenty patients with bronchopneumonia. In only three could causative organisms be detected (two had pneumococci and one had $\mathrm{H}$ influenzae). None had any apparent features of renal involvement; (2) One hundred and fifty healthy blood donors.

\section{ANALYSIS OF ANTI-ENTACTIN ANTIBODIES}

\section{(a) Isolation of entactin}

Entactin was isolated essentially as in our earlier study. ${ }^{9}$ Briefly, glomeruli were isolated from bovine kidneys by sieving procedures as described elsewhere. ${ }^{33}$ Isolated glomeruli were sonicated to remove the cellular debris and obtain GBM. GBM was then briefly homogenised in ten volumes of $6 \mathrm{M}$ guanidine hydrochloride, $0.05 \mathrm{M}$ Tris- $\mathrm{HCl}, \mathrm{pH} \mathrm{7.5}$, containing protease inhibitors as previously described. ${ }^{9}$ The extraction was performed overnight at $37^{\circ} \mathrm{C}$ with continuous stirring. The extract was clarified by centrifugation at $100000 \times \mathrm{g}$ for 60 minutes and the extraction procedure was repeated again with the pellets. The two extracts were then pooled. One hundred and fifty $\mathrm{ml}$ of the guanidine extract was dialysed against three changes of 10 volumes of $6 \mathrm{M}$ urea, $0.05 \mathrm{M}$ Tris- $\mathrm{HCl}, \mathrm{pH}$ $8 \cdot 4$, containing protease inhibitors ${ }^{9}$ and passed over a DEAE Sephacel anion exchange column (Pharmacia, Uppsala, Sweden) equilibrated with the same buffer. The bound proteins were eluted by a linear salt gradient $(0-0.75 \mathrm{M}$ $\mathrm{NaCl}$ ) and the fractions were analysed by SDSPAGE on 6-25\% gradient polyacrylamide slab gels and by ELISA utilising rabbit anti-entactin anti-serum. ${ }^{9}$ Fractions containing entactin were pooled and concentrated to $15 \mathrm{ml}$ by YM10 filter (Amicon, Danvers, USA) and applied to a Sephacryl S-300 gel filtration column (Pharmacia, Uppsala, Sweden) equilibrated with $6 \mathrm{M}$ guanidine- $\mathrm{HCl}, 0.05 \mathrm{M}$ Tris$\mathrm{HCl}, \mathrm{pH} 7 \cdot 5$. The fractions containing entactin were pooled and concentrated to $2 \mathrm{ml}$, dialysed against three changes of $6 \mathrm{M}$ urea, $0.02 \mathrm{M}$ sodium acetate, $\mathrm{pH} 4.8$ containing protease inhibitors and chromatographed on a Mono S cation exchange FPLC column (Pharmacia,
Uppsala, Sweden) equilibrated with the same buffer. The bound proteins were eluted by a linear salt gradient $(0-1 \mathrm{M} \mathrm{NaCl})$. The fractions containing entactin were rechromatographed on a Sephacryl S-300 column to obtain pure entactin. Entactin thus obtained was more than $95 \%$ pure.

\section{(b) Sandwich ELISA}

Antibodies to entactin in sera from various patients were tested by sandwich ELISA as follows: Polystyrene microtitre plates (Nunc, Roskilde, Denmark) were coated with entactin (145 $\mathrm{ng} / \mathrm{ml}$ in $0.05 \mathrm{M}$ sodium carbonate, $\mathrm{pH}$ $9.5 ; 200 \mu l$ in each well) and incubated overnight at room temperature. Plates were washed three times with wash buffer $(0.9 \%$ $\mathrm{NaCl}, 0.05 \%$ Tween 20 ) between each steps. Before adding the sera, plates were blocked with 5\% BSA in PBS overnight at room temperature and rinsed briefly with wash buffer mentioned above. Each serum sample $(200 \mu \mathrm{l})$, diluted $1: 50$ in PBS-Tween-BSA (0.05 $\mathrm{M}$ sodium phosphate, $0.15 \mathrm{M} \mathrm{NaCl}$, $0.05 \% \mathrm{NaN}_{3}, \mathrm{pH} 7.5,0.05 \%$ Tween-20, $2 \mathrm{mg}$ $\mathrm{BSA} / \mathrm{ml}$ ) was then added in triplicate and incubated at room temperature for one hour. Alkaline phosphatase conjugated anti-human IgG/IgM secondary antibodies (Orion, Esbo, Finland) were then added (diluted 1:1000 in PBS-Tween-BSA; $200 \mu \mathrm{l}$ in each well) and plates were again incubated for one hour. Alkaline phosphatase activity was determined by using p-nitrophenyl phosphate (Sigma, St. Louis, USA) at $1 \mathrm{mg} / \mathrm{ml}$ in $1 \mathrm{M}$ diethanolamine buffer, $\mathrm{pH} 9.5$ as the substrate $(200 \mu \mathrm{l}$ in each well). The absorbance was read at zero time and after 30 minutes in a Multiscan microtitre plate reader (Flow, Lugano, Switzerland). The zero value was subtracted from the final readings. Absorbance readings $>2 \mathrm{SD}$ above the average absorbance of the normal sera analysed in the same way were considered positive. In addition to patients' sera, three normal sera and a reference serum [serum from a patient with high titres of antientactin antibodies in our previous study ${ }^{10}$ ] were also incubated concurrently in each ELISA plate. The end point of the assay was determined by measuring the absorbance value of the reference serum $(0.320-0.326$ for IgG and $0.525-0.550$ for IgM anti-entactin antibodies). We did not measure the background binding at 30 minutes since we have a blank and a standard positive and negative controls on each plate. We also know the background values of sera from blood donors and other patients. The reading at time 0 was to correct for irregularities of the plate and substrate.

(c) Characterisation of the assay for anti-entactin antibodies

Anti-entactin antibodies were analysed by an ELISA using purified bovine glomerular entactin as the coating antigen. The specificity of this assay for anti-entactin antibodies has been shown in our previous study. ${ }^{9}$ Using an ELISA inhibition experiment, we showed that whereas preincubation of anti-entactin positive sera with entactin resulted in complete 
inhibition of binding, no inhibition was observed by previous incubation of the sera with another bovine GBM protein, NC1 domain of type IV collagen. ${ }^{34}$ This indicates that the antibodies against entactin are not non-specifically directed against bovine proteins. Addition of BSA in the buffer used for dilution of sera further reduces the possibility of non-specific reaction against bovine proteins.

Proteins from bovine origin may possess carbohydrate epitope, Gal $\alpha$ 1,3 Gal. This epitope is not found in humans although most humans possess natural IgG antibodies against this epitope. ${ }^{35}$ In our assay, we used bovine entactin as the coating antigen. It is thus important to ascertain that antibodies that we analyse in patients' sera are actually antientactin antibodies and not anti-Gal $\alpha 1,3 \mathrm{Gal}$ antibodies. By using ELISA inhibition, we observed that $\mathrm{Gal} \alpha 1,3 \mathrm{Gal}$ was able to block anti-entactin antibodies or entactin was able to block anti-Gal $\alpha$ 1,3 Gal antibodies as described in our previous study. ${ }^{9}$ Thus antientactin and anti-Gal $\alpha 1,3 \mathrm{Gal}$ antibodies are two different antibodies.

SEROLOGICAL TESTS

Anti-nuclear antibodies (ANA) were analysed by indirect immunofluorescence using rat liver substrate while antibodies to native DNA (anti-dsDNA) were detected by the Crithidia luciliae test. ${ }^{36}$ Haemagglutination of RNAseresistant and RNAse sensitive extractable nuclear antigen (ENA) coated red blood cells were used to assay anti-RNP and anti-Sm antibodies. ${ }^{37}$ Anti-SSA and anti-SSB antibodies were detected by Western blotting as previously described ${ }^{38}$ and anti-cardiolipin antibodies by ELISA. ${ }^{12}$ (Analysis of antibodies to ribonucleoprotein (RNP), Smith antigen (Sm), SSA, SSB and cardiolipin were kindly performed by Professor Renee Norberg at the Department of Immunology, National Bacteriological Laboratory, Stockholm). Rheumatoid factor analysis was done by the Rose-Waaler test, using a WHO standard as reference. ${ }^{39}$ The complement components, $\mathrm{C} 1 \mathrm{q}, \mathrm{C} 3$ and $\mathrm{C} 4$, were measured by electroimmunoassay, values being given in percentage of concentrations in a pooled reference serum (normal values of $\mathrm{C} 1 \mathrm{q} 78-130 \%$, C3 70-130\% and C4 53-207\%). ${ }^{40}$

ANA, anti-dsDNA and complement concentrations were measured regularly during the prospective study period while other serological tests were done only at the time of entry.

Table 2 Anti-entactin antibodies in patients with SLE and other control groups

\begin{tabular}{lrrrrr}
\hline & Total cases & \multicolumn{4}{c}{ Anti-entactin } \\
& & IgM & IgG & Botive cases & Total \\
\hline SLE & 79 & 7 & 19 & 5 & 31 \\
Systemic vasculitis & 38 & 0 & 2 & 0 & 2 \\
Rheumatoid arthritis & 25 & 6 & 0 & 0 & 6 \\
Scleroderma (PSS) & 20 & 1 & 0 & 0 & 1 \\
Behçet's syndrome & 5 & 0 & 0 & 0 & 0 \\
Pneumonia & 20 & 1 & 0 & 0 & 1 \\
Normal sera & 150 & 0 & 0 & 0 & 0 \\
\hline
\end{tabular}

STATISTICAL METHODS

Statistical analysis of data was done using Spearman rank correlation, Mann-Whitney U test, Chi square test and Fisher's exact probability test. ${ }^{41}$ Due to multiple statistical testings only $p$ values less than 0.01 were considered significant.

\section{Results}

PRESENCE OF ANTI-ENTACTIN ANTIBODIES IN SLE AND RELATED DISEASES

Of the initial 79 SLE patients, recruited from a defined geographical area, 31 (39\%) had IgG, IgM or both anti-entactin antibodies, irrespective of the severity, activity or clinical features of the disease (table 2). Twenty three of these patients had glomerulonephritis verified at biopsy and $12(50 \%)$ had anti-entactin antibodies. Of the remaining 56 patients without apparent renal involvement, 18 (36\%) were positive for anti-entactin antibodies. Thus, anti-entactin antibodies tended to be more common in patients with renal involvement (Chi square $=2 \cdot 77, \mathrm{p}>0.05$ ).

Anti-entactin antibodies were present much less frequently in other systemic rheumatic diseases (two patients with systemic vasculitis while none of the patients with PSS or Behçet's syndrome had anti-entactin antibodies) (table 2). One exception was rheumatoid arthritis where six of 25 patients possessed IgM anti-entactin antibodies. Five of these patients had severe disease manifestations including vasculitis characterised by mononeuritis multiplex, gangrene of the extremities or gastrointestinal bleeding. None of these patients had apparent renal involvement. Only one patient with pneumonia had anti-entactin antibodies while none of the 150 sera from healthy blood donors had anti-entactin antibodies.

CORRELATION BETWEEN SERUM IgG AND IgM AND THE CORRESPONDING CLASS OF ANTIENTACTIN ANTIBODIES

Polyclonal B cell activation in SLE can nonspecifically raise serum immunoglobulin levels. Thus to ascertain whether the results observed with IgG and IgM anti-entactin antibodies reflect a polyclonal increase of $\mathrm{IgG}$ and $\mathrm{IgM}$, we correlated serum IgG and IgM levels with the titres of the respective class of anti-entactin antibodies. We observed that high titres of antientactin antibodies were associated with both high as well as low serum concentrations of the corresponding class of Ig and vice versa. Thus no significant correlation was observed between the titres of anti-entactin antibodies and the total serum concentration of IgG and IgM. (For IgG, $\mathrm{r}=0.141, \mathrm{p}>0.10$; for $\operatorname{IgM}$, $\mathrm{r}=0 \cdot 130, \mathrm{p}>0 \cdot 10$ ).

CORRELATION OF ANTI-ENTACTIN ANTIBODIES WITH SEVERITY OF SLE

Among patients with mild to moderate disease (Group I), three (30\%) were positive for IgG or IgM anti-entactin antibodies. Six $(60 \%)$ of the patients in group 2 , while five patients 
Table 3 Anti-entactin antibodies in active and inactive phases of the three different group of patients with SLE

\begin{tabular}{|c|c|c|c|c|c|c|c|c|c|}
\hline \multirow[t]{2}{*}{ Group } & \multicolumn{4}{|c|}{$\begin{array}{l}\text { Active phase } \\
\text { Anti-entactin positive cases }\end{array}$} & \multirow{2}{*}{ Group } & \multicolumn{4}{|c|}{$\begin{array}{l}\text { Inactive phase } \\
\text { Anti-entactin positive cases }\end{array}$} \\
\hline & $I g M$ & $\operatorname{Ig} G$ & Both & Total & & $I g M$ & $\operatorname{Ig} G$ & Both & Total \\
\hline Group $1(n=10)$ & 1 & 2 & 0 & 3 & Group $1(n=10)$ & 1 & 2 & 0 & 3 \\
\hline Group $2(n=10)$ & 4 & 2 & 0 & 6 & Group $2(n=10)$ & 2 & 2 & 0 & 4 \\
\hline Group $3(n=10)$ & 1 & 4 & 0 & 5 & Group $3(n=10)$ & 0 & 4 & 0 & 4 \\
\hline Total $(\mathrm{n}=30)$ & 6 & 8 & 0 & 14 & Total $(n=30)$ & 3 & 8 & 0 & 11 \\
\hline
\end{tabular}

$(50 \%)$ in group 3 were positive for IgG or IgM anti-entactin antibodies (table 3). Although anti-entactin antibodies were present more frequently in group 2 and 3 compared with group 1 , the difference between the presence of the antibodies between group 1 or 2 or between group 1 and 3 was not significant $(p=0.15$ and 0.19 respectively). This difference was not significant when the data from patients with severe SLE (group 2 and 3) was pooled together and compared with that of group 1 (mild SLE) $(p=0 \cdot 13)$. These results suggest that anti-entactin antibodies tend to be more common in patients with severe SLE manifestations in the active phase of the disease.

CORRELATION OF ANTI-ENTACTIN ANTIBODIES WITH ACTIVITY OF SLE

The activity of disease was assessed clinically and scored by SLEDAI. The average SLEDAI score in group 1 was $3 \cdot 2$ (range $0-8$ ), that in group $2,3 \cdot 2$ (range $0-8$ ), while the score in group 3 was 13.62 with a range of $0-26$. In some patients, however, the index did not match the clinical minifestations. For instance, one patient had haemolytic anaemia and another had myelitis. Both of these manifestations are not included in SLEDAI. Furthermore, another patient had a long standing nephrotic syndrome and was not given a score in SLEDAI. Nevertheless, no significant correlation was observed between the SLEDAI scores and the titres of IgG $(\mathrm{r}=0.067, \mathrm{p}>0.10)$ and $\operatorname{IgM}(\mathrm{r}=0.033$, $\mathrm{p}>0 \cdot 10$ ) anti-entactin antibodies (fig 1).

Furthermore, pooled data from the three different groups of patients with SLE showed that $14(50 \%)$ of patients were positive for IgG or IgM anti-entactin antibodies in the active phase while $11(40 \%)$ patients were positive in the inactive phase of the disease (table 3 ). This difference was not significant $(p>0.05)$. Thus the presence of anti-entactin antibodies does not correlate with the activity of SLE.

CORRELATION OF ANTI-ENTACTIN ANTIBODIES WITH RENAL INVOLVEMENT IN SLE

As described above, three patients $(30 \%)$ with mild SLE (Group 1), six (60\%) with group 2 while five $(50 \%)$ with significant renal involvement (Group 3) were positive for IgG or IgM anti-entactin antibodies in the active phase (table 3 ). The difference between the presence of anti-entactin antibodies between group 1 and 2, group 1 and 3 or between group 2 and 3 was not significant ( $p>0.05$ in each case). Similarly, in the initial 79 sera examined,
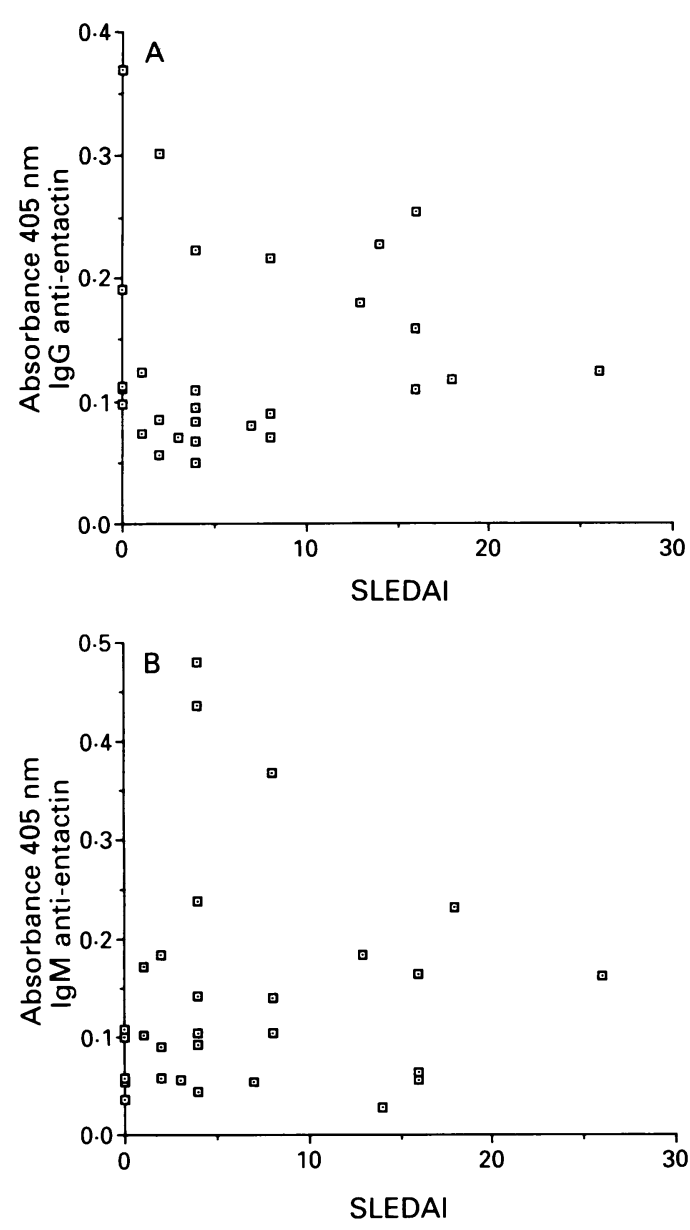

Figure 1 Correlation between serum SLEDAI scores and the titres of $\operatorname{IgG}(i)$ and $\operatorname{IgM}$ (ii) anti-antactin antibodies: no significant correlation was observed between the titres of IgG and IgM anti-entactin antibodies and the SLEDAI scores for the activity of the disease (For IgG, $r=0.067$, $p>0 \cdot 10$; for IgM, $r=0.033, p>0 \cdot 10$ ).

the difference in the presence of anti-entactin antibodies between cases with glomerulonephritis and those without renal lesions was not significant (Chi square $=2 \cdot 77, \mathrm{p}>0.05$ ). Thus no significant difference was observed between the presence of anti-entactin antibodies and renal involvement in SLE.

\section{LONGITUDINAL ANALYSIS OF ANTI-ENTACTIN}

ANTIBODIES

To further assess the relationship of antientactin antibodies with disease activity and response to therapy we analysed anti-entactin antibodies in serial samples of patients with SLE. Twelve sera were available for the study. Of these, five (none from group 1 while 3 from group 2 and 2 from group 3 ) were positive for IgG anti-enactin antibodies. In two patients, the titres of anti-entactin antibodies declined rapidly to normal following treatment whereas in the remaining three the titres remained high even after the disease became inactive following treatment (fig 2).

CORRELATION OF ANTI-ENTACTIN ANTIBODIES WITH OTHER AUTO-ANTIBODIES

SLE is a multi-system autoimmune disorder characterised by the presence of a number of 


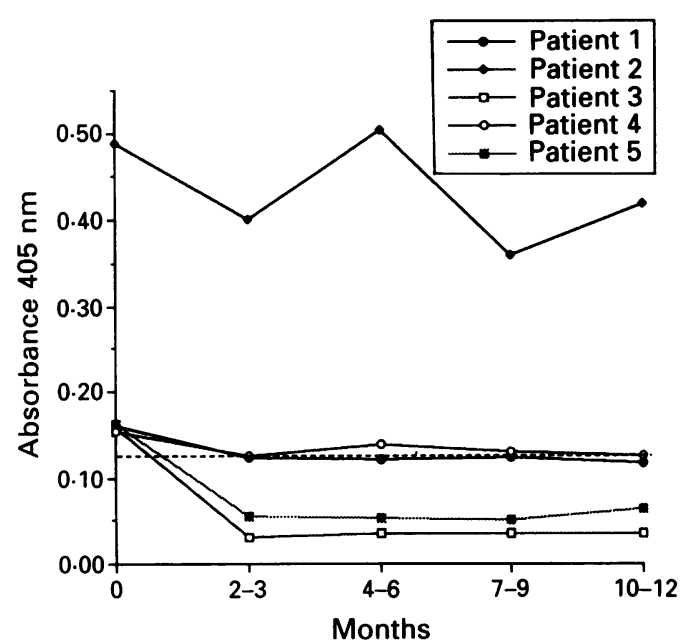

Figure 2 Longitudinal analysis of dnti-entactin antibodies in patients with SLE: there was no significant correlation between the disease activity and the titres of the antibodies during the follow up period.

circulating auto-antibodies. In the present study, we analysed anti-DNA, anti-ENA, antiSSA, anti-SSB anti-Sm and anti-RNP antibodies apart from anti-entactin antibodies. We tried to ascertain whether there is any correlation between the titres of one or more of the aforementioned antibodies with those of anti-entactin antibodies. However, as shown in table 4, no significant correlation was observed between the titres of IgG or IgM anti-entactin antibodies and the titres of anti-DNA, antiENA, anti-SSA, anti-SSB anti-Sm and antiRNP antibodies.

\section{Discussion}

Our results clearly demonstrate that antientactin antibodies are present in a significant number of patients $(40 \%)$ with SLE. We have previously demonstrated the presence of these antibodies in a small group of patients with lupus nephritis verified at biopsy. ${ }^{10}$ The present study was conducted to discover whether antientactin antibodies are specifically associated with renal lesions in SLE. The results show that the patients with anti-entactin antibodies presented with a wide spectrum of clinical features and the antibodies were not associated with any particular clinical sub-group of SLE. While these antibodies were present in a large proportion of patients with lupus nephritis,

Table 4 Correlation between anti-entactin and other autoantibodies in 79 patients of SLE

\begin{tabular}{lcl}
\hline Antibodies & $r$ & $p$ \\
\hline IgG anti-entactin antibodies & & \\
anti-DNA & 0.1333 & 0.2220 \\
anti-ENA & 0.1189 & 0.3030 \\
Anti-SSA & -0.159 & 0.8951 \\
anti-SSB & 0.0076 & 0.9488 \\
anti-Sm & 0.319 & 0.7798 \\
anti-RNP & -0.186 & 0.8708 \\
IgM anti-entactin antibodies & & \\
anti-DNA & 0.0123 & 0.9137 \\
anti-ENA & 0.0171 & 0.8800 \\
Anti-SSA & 0.0671 & 0.5700 \\
anti-SSB & 0.0408 & 0.7307 \\
anti-Sm & -0.1458 & 0.2206 \\
anti-RNP & -0.2128 & 0.0636 \\
\hline
\end{tabular}

they were not solely restricted to this particular group. Further analysis showed that antientactin antibodies tended to be present more frequently in severe disease but the levels of the antibodies did not vary with disease activity or with presence or absence of renal involvement.

It is unclear whether anti-entactin antibodies have any pathogenic significance. Entactin is a ubiquitous component of basement membranes. ${ }^{5-8}$ It is therefore conceivable that the presence of anti-entactin antibodies could lead to widespread connective tissue damage, thus resulting in severe disease manifestations. Conversely, it is also possible that extensive tissue injury in severe SLE could expose entactin to blood leading to the formation of anti-entactin antibodies. If the latter is true, then anti-entactin antibodies should be present in different conditions with extensive tissue damage. However, anti-entactin antibodies were not present in systemic vasculitis like Wegener's granulomatosis and polyarteritis nodosa, which are associated with extensive tissue damage. Moreover, with the exception of rheumatoid arthritis where $24 \%$ of patients with extensive tissue damage had $\operatorname{IgM}$ antientactin antibodies, they were not detected in connective tissue diseases like Behçet's syndrome and progressive systemic sclerosis and inflammatory conditions like pneumonia (table 2). This may indicate that there is probably a fundamental difference in the pattern of tissue damage in different inflammatory conditions that leads to exposure of extracellular matrix proteins and formation of auto-antibodies against them. However, rheumatoid factor effect in patients with rheumatoid arthritis possessing IgM antientactin antibodies cannot be ruled out. It is also possible that anti-entactin antibodies may arise from a process other than tissue injury. Polyclonal B cell stimulation, which is a well known phenomenon occurring in SLE, could be the genesis for these antibodies. Such mechanism generates anti-laminin antibodies in murine models of graft versus host disease. $^{2022}$ However, a negative correlation between the levels of serum IgG and IgM and the titres of the corresponding class of antientactin antibodies makes it an unlikely mechanism in our patients.

To summarise, our study demonstrates that: (1) Anti-entactin antibodies are present in a significant number of patients with SLE and rheumatoid arthritis but not in other systemic rheumatic diseases; (2) Among patients with SLE, anti-entactin antibodies tend to be more common in those with severe disease with or without nephritis than in patients with mild disease manifestations; (3) There is no significant correlation between the titre of antientactin antibodies and the severity or the activity of SLE.

This study was supported by grants from Swedish Institute, 'Medicinska Fakultetens Forskningsanslag', Swedish Medical Research Council (MFR 16X-09487 and B93-27X09528-03B), The Medical Faculty of the University of Lund, The Swedish National Association against Rheumatism, King Gustaf V's 80th Birthday Fund, Greta and Johan Kock's Foundation, Alfred Osterlund's Foundation, Crafoord's Foundation, Thelma Zoega's Fund and Nanna Svartz' Fund. 
1 Kefalides N A, Alper R, Clark C C. Biochemistry and metabolism of basement membranes. Int Rev Cytol 1979; 61: $167-227$

2 Timpl $R$, Weidermann $H$, van Delen V, Furthmayr $H$, Kühn $\mathrm{K}$. A network model for the organization of typ IV collagen molecules in basement membranes. Eur $f$ Biochem 1981; 120: 203-11.

3 Timpl R, Dziadek $M$. Structure, development and molecular pathology of basement membranes. Int Rev Exp Pathol 1986; 29: 1-112.

4 Leblond C P, Inoue S. Structure, composition and assembly of basement membrane. Am f Anat 1988; 185: 367-90.

5 Carlin B, Jaffe R, Bender B, Chung A E. Entactin a novel basal lamina associated sulphated glycoprotein. $\mathcal{f}$ Bio Chem 1981; 256: 5209-14

6 Durkin M E, Chakravarti S, Bartos B B, Liu S Friedman $R$ L, Chung A. Amino acid sequence and domain structure of entactin. Homology with epidermal growth factor precursor and low density lipoprotein receptor. F Cell Biol 1988; 107: 2749-56.

7 Timpl R, Dziadek M, Fujiwara S, Nowack H, Wick G. Nidogen: a new, self aggregating basement membrane protein. Eur f Biochem 1983; 137: 455-65.

8 Mann K, Deutzmann R, Aumailley M, et al. Aminoacid sequence of mouse nidogen, a multidomain basement
membrane protein with binding activity for laminin, membrane protein with binding activity for lamin
collagen IV and cells. EMBO fournal 1989; 8: 65-72.

9 Saxena R, Bygren P, Butkowski R, Wieslander J. Entactin A possible autoantigen in the pathogenesis of nonGoodpasture and anti-GBM nephritis. Kidney Int 1990 38: 263-72.

10 Saxena R, Bygren P, Cederholm B, Wieslander J. Circulating anti-entactin antibodies in patients with glomerulonephritis. Kidney Int 1991; 39: 996-1004.

11 Harris E N, Gharavi A E, Boey M L, et al. Anticardiolipin antibodies: detection by radioimmunoassay and antibodies: detection by radioimmunoassay and association with thrombosis in

12 Sturfelt G, Nived O, Norberg R, Thorstensson R, Krook K Anticardiolipin antibodies in patients with systemic lupus erythematosus. Arthritis Rheum 1987; 30: 1-7.

13 Frampton G, Hicks J, Cameron J S. Significance of antiphospholipid antibodies in patients with lupus nephritis. Kidney Int 1991; 39: 1225-31.

14 Tron F, Bach J F. Relationships between antibodies to native DNA and glomerulonephritis in systemic lupus erythematosus. Clin Exp Immunol 1977; 28: 426-32.

15 Izui S, Lambert P H, Miescher P A. Failure to detect circulating DNA: anti-DNA complexes in systemic lupus circulating DNA: anti-DNA complexes in systemic lup

16 Cavallo T, Grave K, Granholm N A. Murine lupus nephritis. Effects of glucocorticoid on circulating and tissue bound immunoreactants. Lab Invest 1983; 49: 476-81.

17 Izui S, McConahey P J, Clark J P, Hang M L, Hara I, Dixon F J. Retroviral gp70 immune complexes in NZB $\times$ NZW F2 mice with murine lupus nephritis. $\mathcal{f}$ Exp Med 1981; 154: 517-28.

18 Granholm N A, Graves K, Izui S, Cavallo T. Pathogenic role of anti-DNA antibodies in murine lupus nephritis. role of anti-DNA antibodies in murin Lab Immunol 1985; 18: 113-8.

19 Datta S K, Gavalchin J. Origins of pathogenic anti-DNA idiotypes in the NZB $\times S W R$ model of lupus nephritis. Autoimmunity: experimental and clinical aspects. In: Schwartz R S, Rose N R, eds. Ann NY Acad Sci 1986 475: 47-58

20 Bruijn J A, Hoedemaeker P J, Fleuren G J. Biology of disease. Pathogenesis of anti-basement membran glomerulopathy and immune-complex glomerulonephritis: dichotomy dissolved. Lab Invest 1989; 61: 480-8.

21 Bruijn J A, Hogendoorn P C, Corver W E, van den Broek L J, Hoedemaker P J, Fleuren G J. Pathogenesis of experimental lupus nephritis: a role for anti-basement membrane and anti-tubular brush border antibodies in membrane and anti-tubular brush border antibodies in Immunol 1990; 79: 115-22.
22 Bruijn J A, van Leer E H, Baelde $\mathrm{H} \mathrm{J}$, Corver W E, Hogendoorn $P$ C, Fleuren $G \mathrm{~J}$. Characterization and in vivo transfer of nephritogenic autoantibodies directed against dipeptidyl peptidase IV and laminin in experimental lupus nephritis. Lab Invest 1990; 63: 350-9.

23 Fries J F, Holman H R. Systemic lupus erythematosus. A clinical analysis. In: Smith L H Jr, ed. Major problems in internal medicine, vol VI. Philadelphia: W B Saunders, 1976.

24 Tan E M, Cohen A S, Fries J F, et al. The 1982 revised criteria for the classification of systemic lupus criteria for the classification of systemic

25 Bombardier C, Gladman D D, Urowitz M B, Caron D Chang $\mathrm{C} \mathrm{H}$ and the Committee on Prognosis Studies in SLE. Derivation of SLEDAI. A disease activity index for lupus nephritis. Arthritis Rheumat 1992; 35: $630-40$.

26 Hunder G G, Arend W P, Bloch D A, et al. The American College of Rheumatology 1990 criteria for the classification of vasculitis. Arthritis Rheumat 1990; 33: 1065-7.

27 Arnett F C, Edworthy S M, Bloch D A, et al. The American Rheumatism Association 1987 revised criteria for the classification of rheumatoid arthritis. Arthritis Rheumat 1988; 31: 315-24.

28 Jonsson $\mathrm{H}$, Nived $\mathrm{O}$, Sturfelt G. Outcome in systemic lupus erythematosus: A prospective study of patients from a defined population. Medicine $1989 ; 68$ : 141-50.

29 Johnsson H, Nived O, Sturfelt G, Silman A. Estimating the incidence of systemic lupus erythematosus in a defined population using multiple sources of retrieval. $\mathrm{Br} f$ Rheumatol 1990; 29: 492-9.

30 Lightfoot R W, Hughes G R V. Significance of persisting serological abnormalities in SLE. Arthritis Rheumat 1976; 19: $837-43$.

31 Masi A T, Medsger T A, Rodnan G P, et al. Preliminary criteria for the classification of systemic sclerosis (scleroderma). Arthritis Rheum 1980; 23: 581-90.

32 Resnick D. Periodic relapsing and recurrent disorders. In Resnick D, Niwayama G, eds. Diagnosis of bone and join disorders, 2nd ed. Philadelphia: W B Saunders, 1988 1252-64.

33 Wieslander J Bygren P, Heinegard D. Isolation of the specific glomerular basement membrane antigen involved in Goodpasture syndrome. Proc Natl Acad Sci 1984; 81: 1544-8.

34 Hudson B G, Wieslander J, Wisdom B J Jr, Noelken M E Biology of disease. Goodpasture Syndrome: Molecular architecture and function of base

35 Galili U, Schohet S B, Kobrin E, Stults C L M Macher B A. Man, apes, and old world monkeys differ from other mammals in the expression of $\alpha$-galactosyl epitopes on nucleated cells. $\mathcal{F}$ Biol Chem 1988; 263: 17755-62.

36 Aarden L A, deGroot E R, Feltkamp T E W. Crithidia lucilae, a simple substrate for the determination of anti ds-DNA with immunofluorescence technique. Ann NY Acad Sci 1975; 254: 504-15.

37 Sharp G C, Irvin W S, Tan E M. Mixed connective tissue disease, an apparently distinct rheumatic disease syndrome associated with a specific antibody to an extractable nuclear antigen (ENA). Am $\mathcal{F}$ Med 1972; 52: 148-59.

38 Jonsson $\mathrm{H}$, Nived $\mathrm{O}$, Sturfelt $\mathrm{G}$. The effect of age on clinica and serological manifestations in unselected patients with systemic lupus erythematosus. 7 Rheumatol 1988; 15: 505-9.

39 Ball J. Serum factor in rheumatoid arthritis agglutinating sensitized sheep cells. Lancet 1950; 2: 520-24.

40 Siöholm A G. Complement components in normal serum and plasma quantitated by electroimmunoassay. Scand $\mathcal{F}$ mmunol 1975; 4: 25-30.

41 Siegel S. Nonparametric statistics for behavioral sciences. New York: McGraw-Hill, 1956. 